University of Nebraska - Lincoln

DigitalCommons@University of Nebraska - Lincoln

June 2020

\title{
Business Powers of Attorney for Nebraska Farm and Ranch Business Owners
}

J. David Aiken

University of Nebraska-Lincoln, daiken@unl.edu

Follow this and additional works at: https://digitalcommons.unl.edu/ageconfarmmgmt

Part of the Agribusiness Commons, Agriculture Law Commons, Business Law, Public Responsibility, and Ethics Commons, Entrepreneurial and Small Business Operations Commons, Management

Information Systems Commons, Other Business Commons, and the Other Economics Commons

Aiken, J. David, "Business Powers of Attorney for Nebraska Farm and Ranch Business Owners" (2020). Extension Farm and Ranch Management. 34.

https://digitalcommons.unl.edu/ageconfarmmgmt/34

This News Article is brought to you for free and open access by the Agricultural Economics Department at DigitalCommons@University of Nebraska - Lincoln. It has been accepted for inclusion in Extension Farm and Ranch Management by an authorized administrator of DigitalCommons@University of Nebraska - Lincoln. 


\title{
Business Powers of Attorney for Nebraska Farm and Ranch Business Owners
}

\author{
By J. David Aiken
}

May 18, 2020

This information is intended for educational purposes only; it must not be taken as legal advice or as a substitute for legal advice. If you have legal questions about developing and implementing a power of attorney for operating your business should you be unable to do so yourself, contact an attorney.

This publication introduces the POA concept and discusses the Nebraska statutory form POA and its limitations. The purpose is to familiarize the reader with POAs, including their use and misuse, so that they can interact more effectively with their attorney in developing a POA, should they need one.

During this period of coronavirus pandemic, some Nebraskans may be concerned about how business decisions will be made for them if they are unable to make those decision themselves. In some wellstructured businesses, like (1) corporations and (2) partnerships and limited liability companies with comprehensive operating agreements, there are formal chains of command, so it is legally clear who can substitute for the incapacitated business owner. In other, more informally structured businesses, such as partnerships operating with minimal or no written partnership agreements and many family operations, there is no clear chain of command and the business could grind to a halt until the incapacitated business owner is able to assume at least some of their business functions. If the farm or ranch is co-owned with a spouse or other relative, they may have the necessary legal authority to make important business decisions should the need arise. Consult your attorney to see whether your current business structure provides adequate legal and business backup should you become unable to operate the business yourself.

In the case where there is no well-structured legal documentation of who assumes business functions when a key manager is incapacitated — which would likely include many Nebraska farms and ranches the business owner may seek to provide business operational continuity should they become unable to do so. The most convenient way to do this is through executing a power of attorney (POA). While there are online POA forms available, I cannot recommend them for anything other than dealing with a very sudden emergency situation. The powers granted in a checkbox POA form are, in my professional opinion, far too broad to grant without significant built-in safeguards and limitations. So, for most farms and ranches, I strongly recommend visiting with your attorney to develop a POA appropriate to your specific circumstances. 
What is a POA? A POA is a legal document in which the principal delegates specified decision-making authority to the agent. POAs are often used to authorize agents to conduct elements of the principal's business affairs or financial affairs. POAs may be designed to address a variety of business and financial activities. I will refer to business POAs in this publication as we are focusing on use of a POA to safely allow for business continuation when one of the business owners becomes incapacitated.

Why might a farm or ranch owner need a POA? If the owner is hospitalized and unable to make business decisions or sign important business documents, the POA can authorize the agent to do so instead. In the absence of a POA, a court proceeding is needed to appoint a guardian or conservator to make these decisions in the absence of the incapacitated business owner, or the decisions would not be made, and the business would suffer any consequences.

What types of business and financial decisions can the POA agent make for me? In the Nebraska statutory POA form, an agent may be authorized to take any action that the principal could take on their own. Please note that this is a very broad grant of legal authority - the agent could sell the business, pledge it as loan collateral, purchase additional land, livestock or equipment in cash or on credit, and so forth if the business owner could do so himself or herself. So, you should have absolute faith in your POA agent to always do the right thing, or else build in some checks and balances or limitations on authority in your POA document.

The specific general authorities that may be delegated to a POA agent under the Nebraska Uniform Power of Attorney Act are to take any action that the principal could take regarding: (1) real estate, (2) tangible personal property, (such as crops, livestock, machinery, etc.), (3) stocks and bonds, (4) commodities and options, (5) banks and financial institutions, (6) operation of entity or business, (7) insurance and annuities, (8) estates, trusts and other beneficial interests, (9) claims and litigation, (10) personal and family maintenance, (11) benefits from governmental programs or civil or military service, (12) retirement plans, and (13) taxes. The principal can delegate some or all of these areas of general authority to the POA agent.

The Nebraska Uniform Power of Attorney Act has optional grants of specific authority generally regarding the principal's estate plan. The specific grants of specific authority are to take any action that the principal could take regarding (1) creating, amending, revoking or terminating an inter vivos ("living") trust; (2) making a gift, (3) creating or changing rights of survivorship, (4) creating or changing a beneficiary designation, (5) delegating to another person to exercise the authority granted under the POA, (6) waive the principal's right to be a beneficiary of a joint and survivor annuity, including a survivor benefit under a retirement plan, (7) exercise fiduciary powers that the principal has authority to delegate; and (8) renounce or disclaim an interest in property, including a power of appointment. These acts of specific authority principally pertain to making changes to fairly complex estate plans, which could have major estate tax consequences as well as changing the distribution of your estate. 
Under the statutory form, the principal can describe limitations on any authority granted in the POA. If you truly need a POA, you also need the advice of an attorney to help you sort through these options to develop a POA that best meets your specific needs.

How do I select my POA agent? This is a hugely important issue. The agent should be familiar with your business and have sufficient experience to be able to make sound management decisions when they are needed. If the business needs on-site supervision, the agent should be able to oversee the business in person. The agent should also be absolutely trustworthy. Even the most carefully crafted POA cannot prevent every possible misuse of POA authority by the determined agent. You do not want to give POA authority to an agent who may not be able to resist the temptation that the POA provides to feather the agent's own nest at the expense of the principal and his or her family and business. Sometimes bonded professional agents (such as a professional farm manager or a bank trust officer) may make good POA agents if you are uncomfortable using a family member or business employee.

Agents are entitled to reasonable compensation for their services unless otherwise provided in the POA.

How do I appropriately limit the agent's POA authority? The best way is to have an attorney prepare your POA. By way of comparison, in Nebraska, corporations can undertake certain extraordinary activities only with the consent of the shareholders, such as (1) a voluntary dissolution of the corporation; (2) mergers, consolidations, or the sale of all or most of the corporate assets; and (3) mortgages, sales, or leases of corporate property not in the regular course of business. Note that an agent for a non-corporate principal would be able to do any of these things without any oversight or approval unless the business POA specifically provides otherwise. It might be appropriate to consider what types of routine business actions the agent could take without supervision, and what other types of actions might require consultation with the principal's family members, the business's managers, etc.

When does the POA take effect? There is broad discretion here. You can establish in the POA to, for example, allow it to go into effect when your physician certifies in writing that you are unable to make decisions for yourself.

Can I revoke a business POA? Yes. The POA may be revoked by the principal at any time. You make POA revocation effective by destroying all copies of the POA, by notifying the agent by certified mail, and by notifying all third parties who may be relying on the POA for the agent's authority to conduct business on behalf of the principal.

Who can challenge an agent's authority in court? The principal, the principal's parents, spouse, children and grandchildren, and the principal's guardian or conservator, among others.

How can I get a business POA form? A link to the Nebraska Supreme Court POA forms and brief instructions on completing and executing the form are at the end of this publication. In my opinion, you should work with an attorney to develop a customized business POA. 


\section{Additional Resources}

Nebraska Supreme Court POA forms and instructions - for both general and health care POAs: https://supremecourt.nebraska.gov/self-help/medical/power-attorney-medical

Joe Hawbaker, Durable Powers of Attorney. https://farmerandrancher.org/articles/ and click on "durable power of attorney". There are many other equally helpful documents by Mr. Hawbaker, an Omaha attorney, on this web page pertaining to estate planning for Nebraska farm and ranch families.

J. David Aiken is a Professor and Water and Agricultural Law Specialist in the Department of Agricultural Economics. 